\title{
LIGHT AND ELECTRON MICROSCOPY OF THE SWEAT GLANDS OF THE DROMEDARY CAMEL
}

\author{
A. A. M. TAHA, A. B. ABDALLA \\ Department of Anatomy, Faculty of Veterinary Science, P. O. Box 32, Khartoum North, Sudan
}

Received fanuary 31, 1979

\begin{abstract}
Taha A. A. M., A. B. Abdalla: Light and Electron Microscopy of the Sweat Glands of the Dromedary Camel. Acta vet. Brno, 49, 1980: 31-35.

A light and electron microscopic study was made on the sweat glands of the dromedary camel using 42 experimental animals. The glands were present in all the regions studied except the lips, external nares and perianal region. The secretory tubule was made up of columnar, cuboidal or, sometimes, flat epithelium. No glycogen was detected in the gland. Cell organelles were few but mitochondria were numerous. There was no evidence that the gland was of the classical apocrine type.
\end{abstract}

Body regions, secretory cells, organelles.

Only few studies have as yet been made on the structure of the sweat glands of the dromedary camel. Dowling and Nay (1962) stated that the secretory cells of the sweat glands of the camel were cuboidal to columnar. Lea and Schmidt-Nielsen (1962) studied 23 regions of the skin of two Saharan camels. Their findings indicated that the sweat glands were present in all the skin areas studied with the exception of the lips, external nares and the perianal region. The secretory cells were of the low columnar type.

On the other hand numerous studies have been made on the structure of the sweat glands in other mammals. With the light microscope the sweat glands have been studied in the horse ( $\mathrm{Ta}$ kagi and Tagawa 1959), dog (Takahara and Ka to 1965), cattle (Hafez, Badreldin and Shafei 1955; Gold sberry and Calhoun 1959; Nay 1959; Jenkinson and Nay 1975), water buffalo (Prusty 1971, 1973; Jenkinson and Nay 1975) and goat and sheep (Jenkinson and Nay 1975). The ultrastructure of the sweat glands has been studied in cattle (Prasad 1973). It is now generally held that the sweat glands of mammals are of the classical apocrine type.

The present investigation is intended to throw more light on the histology of the sweat glands of the camel. Moreover, it is clear that there has so far been no ultrastructural study of the glands of this animal.

\section{Materials and Methods}

Material for this study was collected from Tambul camel market, about 120 kilometres to the South of Khartoum. Forty-two adult camels were used, of which 15 were males and 27 females.

For the study of the distribution and histology of the glands, pieces of the skin were taken from 33 regions of the body (Table 1) immediately after the animal was killed. The tissue was fixed in $10 \%$ formol saline, Bouin's or Lavdowsky's fixative, dehydrated in alcohol, cleared in Cedarwood oil and embedded in paraffin. Sections, 8-10 $\mu \mathrm{m}$ thick, were stained with haematoxylin and eosin. Selected sections (Table 1) were stained with the periodic acid-Schiff reagent (P. A. S.) for glycogen, with or without prior treatment with malt diastase.

For electron microscopy pieces of the skin were taken from the left lateral aspect of the neck of two adult females. The tissue was fixed by immersion in $3 \%$ glutaraldehyde in $0.2 \mathrm{M}$ cacodylate buffer ( $\mathrm{pH}$ 7.4) with sucrose. After 24 hours the tissue was thoroughly washed in the buffer, post-fixed for two hours in $2 \%$ osmium tetroxide in the same buffer and block-stained in $2 \%$ 
Fig. 1.

Sweat gland from the scrotum. Two tubules show nuclei (arrows) in the lumina. H \& E. $\times 820$.

Fig. 2.

Two secretory cells are full of secretory granules (SG, $\left.S^{\prime}\right)$. The secretory granule $S^{\prime} G^{\prime}$ is closely related to what appears as a mitochondrion
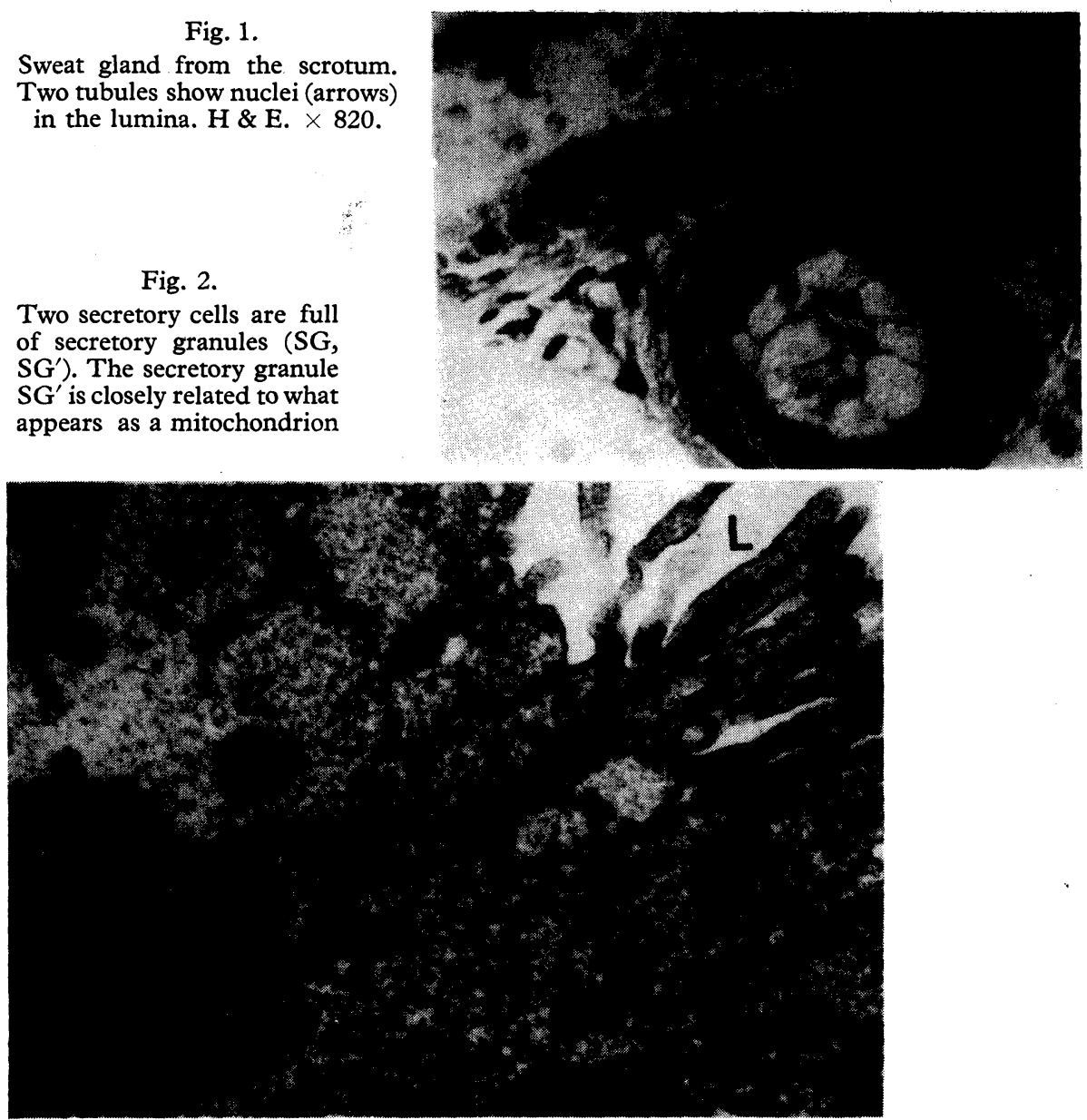

(arrow). A peripherally-situated dense body $(B)$ is present in the secretory granule. The two cells make contact without infoldings. Desmosomes (D) are present at the contact between cells. $M$ mitochondrion, $\mathrm{V}=$ microvilli, $\mathbf{L}=$ lumen. Cacodylate - buffered glutaraldehyde and osmium tetroxide $\times 2800$.

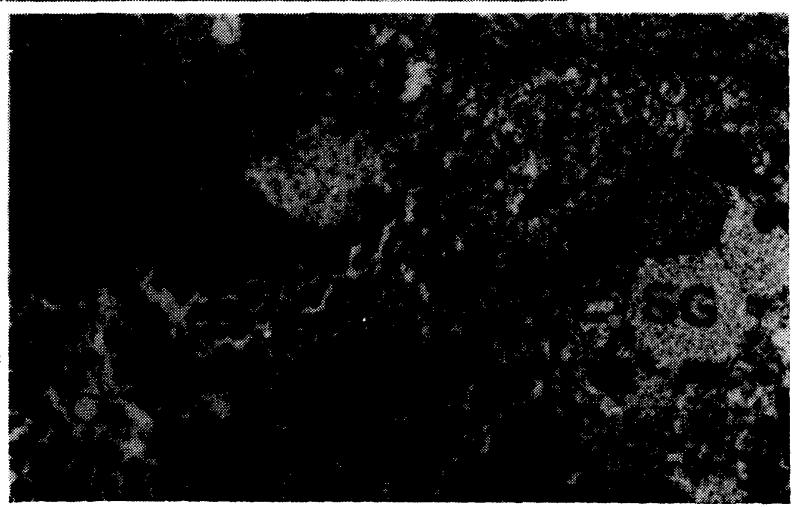

Fig. 3.

Five secretory cells. One secretory granule (SG) is light while another one (on top of it) is dark. A portion of a cell $(P)$ is found in the lumen of the right. Cacodylate - buffered glutaraldehyde osmium tetroxide $\times 10000$. 


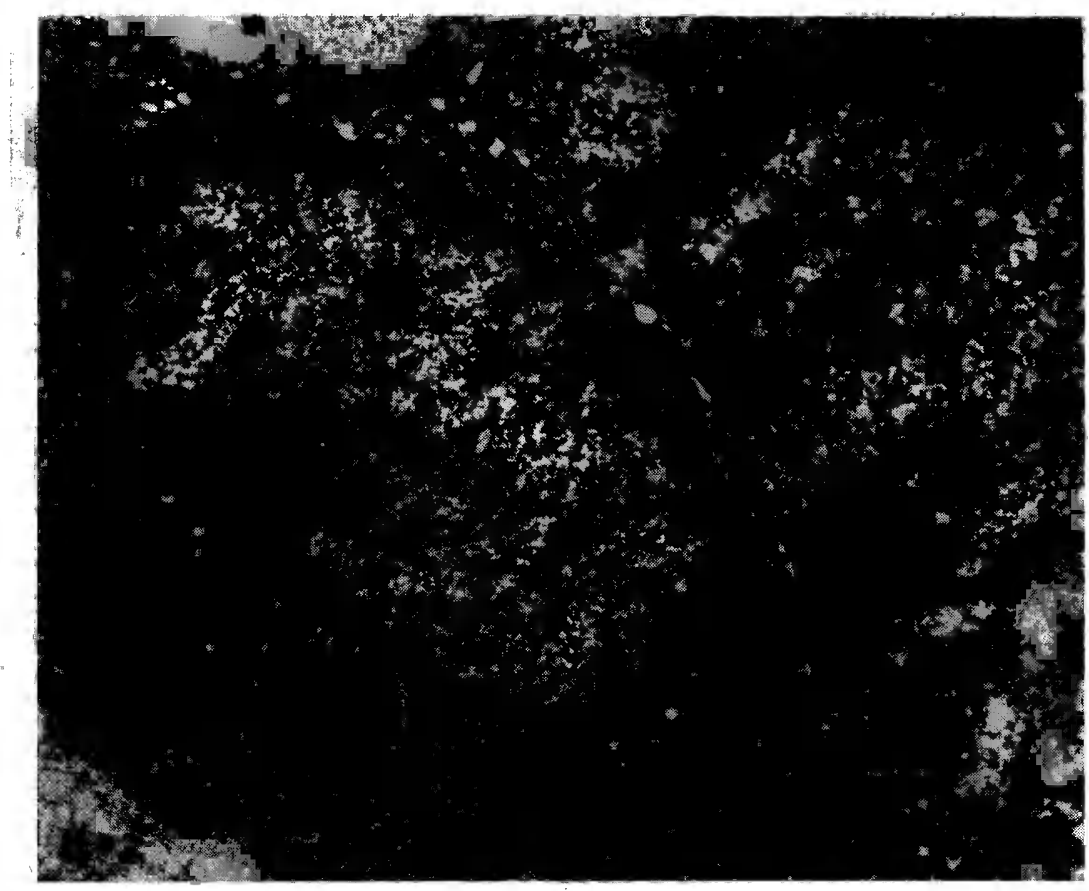

Fig. 4.

Secretory cell and myoepithelial cell. The nucleus $(\mathbf{N})$ of the secretory cells is basally situated. Secretory granules (SG) are present in all the cell except the narrow area between the nucleus and the basal membrane. The latter shows many infoldings (arrows). $M E=$ myoepithelial cell. Cacodylate - buffered glutaraldehyde and osmium tetroxide $\times 18600$. 
Table 1

The regions of the skin of the camel investigated

The sweat glands were studied in all thirty three regions. In addition some regions $(+)$ were also tested with the periodic acid-Schiff technique. Electron microscopy was made on the skin of the neck.

Region

1. Upper lip ${ }^{+}$

2. Lower lip ${ }^{+}$

3. External nares ${ }^{+}$

4. Upper eyelid

5. Lower eyelid

6. Cheek ${ }^{+}$

7. External ear

8. Poll $^{+}$

9. Neck-dorsal

10. Neck-ventral

11. Neck-lateral

12. Forearm-lateral

13. Forearm-medial ${ }^{+}$

14. Carpus-dorsal

15. Carpus-volar

16. Metacarpal-lateral

17. Forelimb-interdigital
Region

18. Back-front

19. Hump ${ }^{+}$

20. Back-hind

21. Thorax-lateral ${ }^{+}$

22. Abdomen-lateral ${ }^{+}$

23. Abdomen-ventral

24. Flank

25. Tail

26. Perianal ${ }^{+}$

27. Thigh-lateral \pm

28. Thigh-medial ${ }^{+}$

29. Tarsus-drosal

30. Tarsus-plantar

31. Hindlimb-interdigital

32. Scrotum ${ }^{+}$

33. Mammary gland

uranyl acetate. The specimen was dehydrated in cold methanol for two hours, cleared in acetone at room temperature for one hour and embedded in epoxy resin. Ultrathin sections were cut on a Reichert OMU2 ultratome, stained with lead citrate and examined in an AE1 EMB6 electron microscope at $60 \mathrm{Kv}$.

\section{Light microscopy}

\section{Results}

The sweat glands were found in all the body areas examined except the lips, the external nares and the perianal region. The glands were always associated with the large cover hair, clustered around the hair bulb in the reticular layer of the dermis. The secretory tubules varied greatly in size. In some regions, e. g. the scrotum, medial aspect of the arm, the tubules were large, whereas in other regions, e. g. ventral aspect of the neck, the glands were relatively small. The tubules were lined with tall columnar of cuboidal cells. The columnar cells often showed apical protrusions. These apical protrusions might be present of some and not all the columnar cells of the same tubule. Occasionally tubules lined with flat epithelium were seen. Adjacent tubules might show one or the other of the type of epithelium. The secretory cells possessed oval, basally situated nuclei, and rest on myoepithelial cells. The lumen of the tubule was filled with globular material in which nuclei were often seen (Fig. 1).

The gland duct was narrower than the secretory tubule. It had a lining of two layers of cuboidal cells, although sometimes, as in the interdigital region, more than two layers of cuboidal cells might be seen.

The secretory cells were intensely and uniformly reactive to P.A.S. test. The granular reaction, which was resistant to diastase digestion, was confined to the supranuclear region. The lumina of the tubules and the ducts were consistently unreactive.

\section{Electron microscopy}

The secretory cells were polyhedral in shape, with rounded or oval nuclei situated towards the base. Adjacent cells made contact in an almost straight line with no infoldings; desmosomes were present at these contacts. The luminal cell 
membrane presented microvilli which protruded into the lumen of the tubule. Most of the microvilli of one cell might be cut along their long axis, while those of an adjacent cell might be cut transversely. The secretory cell was characterized by a paucity of cell organelles, but mitochondria were numerous. Occasionally a structure, which was probably a portion of a mitochondrion was seen almost enclosed in the secretory granule. The granules often contained a dense peripherally-situated body (Fig. 2). Examination of the glandular lumen failed to show any secretory granules. Some sections showed what might be mistaken for a secretory granule, but closer inspection would reveal that it was in fact a portion of the cell (Fig. 3). In the secretory cell, the granules were distributed in all parts of the cytoplasm except the narrow area between the nucleus and the base of the cell. The base of the secretory cell made numerous infoldings at its contact with the myoepithelial cell (Fig. 4).

Nerve fibres were not seen close to either the secretory or the myoepithelial cell.

\section{Discussion}

The present study showed that the lining of the secretory tubule of the sweat gland varied between columnar with apical protrusions to cuboidal or even flat epithelium. This is quite similar to the findings of Dowling and Nay (1962), although Lee and Schmidt - Nielsen (1962) saw only low columnar cells. Whereas in most species of Bovidae the lining of the secretory tubule of the sweat gland was of cuboidal cells, in cattle and wild beast the lining was of flat cells (Jenkins on and Nay 1975).

The significance of this variation in the height of the secretory cells is not clear. It is probable that the variation was a result of the state of dilatation of the tubule, so that when the tubule was excessively dilated the lining epithelium became flat, as has been explained for the sweat glands of man (Montagna et al. 1953). In a study of the skin of the Egyptian buffaloes and cattle, Hafez et al. (1955) maintained that in each of these two species the sweat glands existed in two forms. The first form was a typical apocrine, with the glandular epithelium made up of columnar cells with cytoplasmic protrusions; the lumen of these glands contained a stained material. The second form was made of tubules of cuboidal or flattened cells and empty lumina. Hafez et al. (1955) regarded this second form as eccrine. On the other hand Montes et al. (1960) stated that the extent of the apical protrusions of the lining cells in man was influenced by the rate of secretory activity, the type of fixative, and the time elapsing between death and fixation.

The secretory cells of the sweat glands of the camel contained a P.A.S. positive, diastase-resistant material. It was, therefore, clear that there was no demonstrable glycogen in these cells. This is similar to the findings in the sweat glands of the horse (Takagi and Tagawa 1959), dog (Takahara and Kato 1965) and bovine (Prasad 1973). The stained material could likely be a carbohydrate-protein complex.

Ultrastructurally, the secretory cells of the sweat glands of the camel were characterized by a number of features. First, there was a paucity of cell organelles but mitochondria were numerous. Secondly, although many infoldings of the cell membrane were present on the basal part of the cell, adjacent cells made contact in an almost straight line. It is of interest to note that Prasad (1973) described infoldings on both the basal part of the cell and between adjacent cells 
in bovine. Thirdly, the gland lumina were empty and contained neither nuclei nor anything that might clearly be regarded as a secretion. However, as already described, cell portions were occasionally seen in the lumen of the tubule; it is likely that the long axes of these portions of the cell were perpendicular to the plane of section as described in man by Montes et al. (1960). Fourthly, no axons were seen in close contact with either the secretory cell or the myoepithelial cell. This was in agreement with the already published reports on the absence of innervation of the sweat glands in the camel (Rollinson, Injidi and Jenkinson 1972) or in sheep, goat, dog and cat (Jenkinson and Blackburn 1967, 1968).

The close relationship between the mitochondria and the secretory material in the cells might indicate that the mitochondria were somehow incorporated in the secretory material. This hypothesis had already been propounded by $\mathrm{Ni}$ colas et al. (1914). The results obtained in this study would lend support to this hypothesis, but the evidence was not conclusive.

The mode of secretion of sweat glands has for long been a subject of controversy. Lee and Schmidt-Niels en (1962) could not determine whether the glands in the camel were of the classical apocrine type; their specimens did not show any example of low cuboidal epithelium or of a distinct well developed apical protrusions. Nevertheless, Lee and Schmidt-Nielsen thought that the presence of secretory granules in the apices of the cells and the bleb-like protrusions on these cells might indicate the possibility of apocrine secretion. In this study, secretory granules were found in all parts of the cell except a narrow basal part. Moreover, the only indication of apocrine secretion was the presence of nuclei in the lumina in histological sections. There were no nuclei in the lumina of glands studied with the electron microscope and no indication of the presence of a definite secretory material. The presence of nuclei in the lumina in histological sections could, however, be a result of trauma (Montes et al. 1960); it is also possible that a few cells were obliquely cut so that their nuclei appeared in the lumen. Jenkinson (1967) was of the opinion that there was little justification for the continued use of the term "apocrine sweat gland". He was, perhaps, correct in suggesting that classification of sweat glands by mode of action should be avoided until more was known about the physiology of these glands in individual species.

\section{Acknowledgements}

The authors wish to thank the Graduate College, University of Khartoum for financial aid, and Dr. S. E. I. Adam, Department of Clinical Studies, Faculty of Veterinary Science for helpful criticism.

\section{Histologie a elektronová mikroskopie potních žláz velbloudů}

Histologické a elektron-mikroskopické sledování 42 pokusných zviŕat ukázalo, že potní žlázy se vyskytují na celém povrchu těla velbloudů mimo pysků, vnější části nozder a perianální krajiny. Sekreční tubuly se skládají z cylindrického, kuboidálního a místy plochého epitelu. Ve žlázách nebyl nalezen glykogen. Buněčné organely jsou málo početné, pouze mitochondrie jsou početnější. Na základě prezentovaných nálezů lze konstatovat, že potní žlázy velbloudů nepatří $\mathrm{k}$ apokrinnímu typu. 


\section{Гистология и электронная микроскопия потовых желез верблюдов}

Гистологические и электронно-микроскопические исслдования 42 подопытных животных выявили, что потовые железы расположены по всей поверхности тела верблюдов, за исключением губ, 'наруженой части ноздрей и. перианальной части. Секреторные канальцы состоят из цилиндрического, кубического и местами плоского эпителия. В железах не был выявлен гликоген. Клеточные организмы малочисленные, лишь митохондрии несколько превосходят численностью. На основе указанных результатов можно отметить, что потовые железы верблюдов не принадлежат к апокринному типу.

\section{References}

DOWLING, D. F. - NAY, T.: Hair follicles anc the sweat glands of the camel. Nature (London), 195, 1962: 578.

GOLDSBERY, S. - CALHOUN, M. L.: Comparative histology of the skin of Hereford and Aberdeen Angus cattle. Am. J. vet. Res., 20, 1959: 61.

HAFEZ, E. S. E. - BADRELDIN, A. L. - SHAFEI, M. M.: Skin structure of Egyptian buffaloes and cattle with particular reference to sweat glands. J. Agric. Sci., 46, 1955:19.

JENKINSON, D. M.: On the classification of sweat glands and the question of the existence of the apocrine secretory process. Br. vet. J., 123, 1967: 311.

JENKINSON, D. M. - BLACKBURN, P. S.: The distribution of nerves, monoamine oxidase and cholinesterase in the skin of sheep and goat. J. Anat., 101, 1967: 333.

JENKINSON, D. M. - BLACKBURN, P. S.: The distribution of nerves, monoamine oxidase and cholinesterase in the skin of the dog and cat. Res. vet. Sci., 9, 1968: 521.

JENKINSON, D. M. - NAY, T.: The sweat glands and hair follicles of different species of bovinae. Aust. J. Biol. Sci., 28, 1975: 55.

LEE, D. G. - SCHMIDT-NIELSEN, K.: The skin, sweat glands and hair follicles of the camel (Camelus dromedarius). Anat. Rec. 143, 1962: 71.

MONTAGNA, W. - CHASE, H. B. - LOBITZ, W. C.: Histology and cytochemistry of human skin. V. Axillary apocrine sweat glands. Am. J. Anat., 92, 1953: 451.

MONTES, L. F. - BAKER, B. L. - CURTIS, A. C.: The cytology of the large axillary sweat glands in man. J. Invest. Dermatol., 35, 1960: 273.

NAY, T.: Sweat glands in cattle: Histology, morphology and evolutionary trend. Aust. J. agric. Res., 10, 1959: 121.

NICOLAS, J. - REGAUD, C. - FAVRE, M.: Sur la fine structure des glandes sudoripares de I "home" particulierement en cas que concerne les mitochondries et les phenomenes de secretion. 17th. Intern. Congr. Med., Sect. 13, Dermatol. Syphilis, 1914: 105.

PRASAD, G.: Observations on the fine structure of bovine sweat glands. Nord. Vet. Med., 25, 1973: 163.

PRUSTY, J. N.: Sweat gland morphology of the Indian water buffalo. Ind. J. Anim. Hlth. 10, 1971: 163.

PRUSTY, J. N.: Role of sweat glands in heat regulation in Indian water buffalo. Ind. J. Anim. Hlth. 12, 1973: 33.

ROLLINSON, D. H. L. - INJIDI, M. H. - JENKINSON, D. M.: The distribution of nerves, monoamine oxidase and cholinesterase in the skin of camel (Camelus dromedarius). Res. vet. Sci., 13, 1972: 304 .

TAKAGI, S. - TAGAWA, M.: A cytological and cytochemical study of the sweat glands of the horse. Jap. J. Physiol. 9, 1959, 153.

TAKAHARA, H. - KATO, Y.: Functional histology of the sweat glands of the dog. 1. Histological and cytochemical observations of the normal apocrine sweat gland. Science Bulletin Faculty of Agriculture, Kyushu University. 21, 1965: 329. 